\title{
Malignant Fibrous Histiocytoma-Amplified Sequence 1
}

National Cancer Institute

\section{Source}

National Cancer Institute. Malignant Fibrous Histiocytoma-Amplified Sequence 1. NCI

Thesaurus. Code C33941.

Malignant fibrous histiocytoma-amplified sequence 1 (1052 aa, 117 kDa) is encoded by the human MFHAS1 gene. This protein may play a role in cell cycle regulation. 